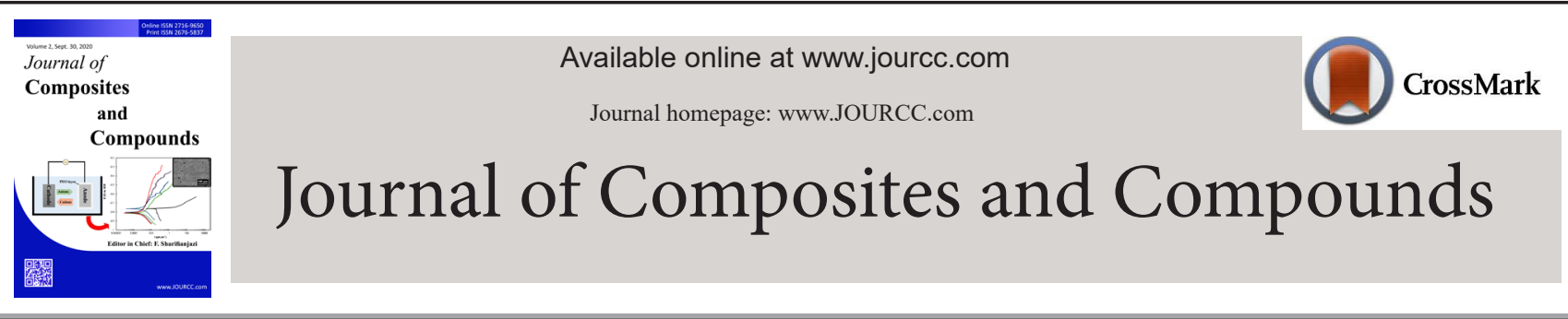

\title{
A review on development and application of self-healing thermal barrier composite coatings
}

\author{
Aliasghar Abuchenari ${ }^{a}$, Hadi Ghazanfari ${ }^{b *}$, Mostafa Siavashi ${ }^{c}$, Maryam Sabetzadeh ${ }^{d}$, Sajad Talebi ${ }^{e}$, \\ Zahra Karami Chemeh ${ }^{f}$, Ata Jamavari ${ }^{g}$ \\ ${ }^{a}$ Materials Engineering, Shahid Bahonar University, Kerman, Iran \\ ${ }^{b}$ Department of Mining, Metallurgical and Materials Engineering, Université Laval, Québec G1V 0A6, QC, Canada \\ ${ }^{c}$ Faculty of Engineering, Christian-Albrechts-University Kiel, Germany \\ ${ }^{d}$ Chemical Engineering Department, Polymer Group, Isfahan University of Technology, Isfahan, Iran \\ ${ }^{e}$ Department of Materials and Metallurgy, Faculty of Engineering, University of Arak, Arak, Iran \\ ${ }^{f}$ Department of textile Engineering, Amirkabir University of Technology, Tehran, Iran \\ ${ }^{g}$ Department of Material Science and Engineering, University of Science and Technology, Tehran, Iran
}

\begin{abstract}
A B S T R A C T
A R T I C L E IN F O R M A T I O N

To improve the hot section metallic parts durability in advanced gas-turbine operating in power generation and Article history:

aircraft, thermal barrier coating (TBCs) are extensively utilized to increase their lifetime. The reason for applying Received 15 May 2020

coatings on these components is the improvement of their physical properties, mechanical properties, and outer Received in revised form 24 August 2020

look. The self-repairing ability of materials is very promising due to expanding the service time of materials and Accepted 10 September 2020

it is also beneficial in terms of human safety and financial aspects. In this review article, structure, properties, limitations, and the modification approaches of TBCs were studied. In addition, self-healing agents for TBCs including $\mathrm{SiC}, \mathrm{MoSi}_{2}, \mathrm{TiC}$ were introduced, which release their oxide by reaction with air and $\mathrm{O}_{2}$ that are able to heal the pores/cracks in the coatings. In this regard, their coating methods, mechanism, and applications in TBCs were reviewed.

(C)2020 JCC Research Group.

Keywords:

Thermal barrier coating (TBC)

TBC lifetime

TBC modification

Self-healing composite

Peer review under responsibility of JCC Research Group
\end{abstract}

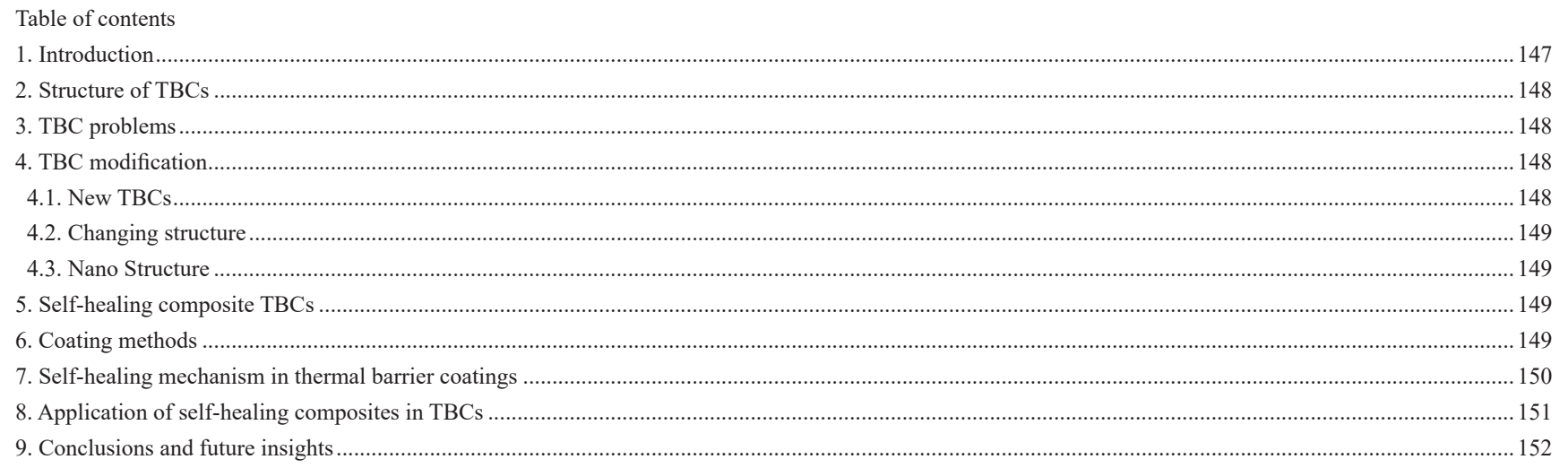

\section{Introduction}

Most industrial processes involve operating under harsh environments of high temperature, high pressure, increased temperature gradients, and foreign object damage (FOD), corroding and oxidizing atmosphere, and large stresses on individual components. Marine, aero, and industrial gas turbines are examples of such industrial processes [1].

*Corresponding author: Hadi Ghazanfari; E-mail: hadi.ghazanfari.1@ulaval.ca DOR: 20.1001.1.26765837.2020.2.4.6.8

https://doi.org/10.29252/jcc.2.3.6 This is an open access article under the CC BY license (https://creativecommons.org/licenses/by/4.0)
Coatings on the surface of materials improve materials appearance, mechanical, and physical properties [2-4]. A thick barricade will be built on the surfaces of metals by the coating against atmospheric oxygen and water [5-7]. Thermal barrier coatings (TBCs) are extensively utilized for the durability enhancement of hot metallic components operating in advanced gas turbines or power generation and aircraft [8]. However, the initiation of cracks, their propagation, and coalescence result in the coating spallation, which exposes the hot-section metallic components \section{.}

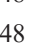


to high temperature and oxidation $[9,10]$.

In the past 15 years, a considerable section of research activities has been allocated to self-healing materials [11-13]. The aim of using self-healing materials is to restore the mechanical and physical integrity and properties rapidly after being damaged. The self-repairing ability of materials is a treasured characteristic due to expanding the material service period offering benefits in terms of financial aspects and human safety requirements $[5,14]$.

This review article focuses on the TBCs and their structures, restrictions, and modifications techniques [15]. Subsequently, self-healing materials and self-healing composite TBCs are introduced, and finally, their coating methods, mechanism, and applications in TBCs are discussed [16].

\section{Structure of TBCs}

In order to protect metallic parts of vanes, blades, and combustion chambers in jet engines and gas turbines from oxidation and corrosion at high temperatures, TBCs are often applied on their surfaces [17-19]. The TBCs primary function is to enable the hot operating parts to bear higher service temperatures beyond the underlying metals limit temperature. When the hot sections are protected by TBCs with a thickness in the range of 150 to $800 \mu \mathrm{m}$, the inlet temperature can be increased by 100 to $300{ }^{\circ} \mathrm{C}[20]$.

There are three layers in the TBC structure applied on the surface of a metallic substrate: 1) the bond-coat (BC) applied on the surface of the substrate; 2) thermally grown oxide (TGO), which is generated at the $\mathrm{BC} / \mathrm{TC}$ interface; 3) the ceramic top-coat (TC) [21]. BC and TC commonly consist of MCrAlY (M can be $\mathrm{Co}, \mathrm{Ni}, \mathrm{Fe}$, or their combinations) layer, and zirconia that is partially stabilized with Yittria (YSZ), respectively. The TGO oxide layer mostly composed of $\mathrm{Al}_{2} \mathrm{O}_{3}$, is generated at the $\mathrm{BC} / \mathrm{TC}$ interface during high-temperature service in the air $[22,23]$. YSZ has a porous structure and with the increase in service time, oxygen penetrates the coating or cracks and reacts with the bond coat materials. Due to this reaction, the TGO layer grows by the metallic BC selective oxidation and is mainly composed of alumina. One of the main reasons for cracking, delamination, and spallation of YSZ has been reported to be the TGO layer growth [24-27].

Zirconia-based coatings are favored in TBCs owing to their relatively high thermal expansion coefficient (TEC), good oxidation resistance, good thermal shock resistance low thermal conductivity, and good microstructure stability [28, 29].

\section{TBC problems}

Propagation of cracks in TBCs during the service period leads to the coating delamination and failure of TBC coatings on hot components [9, 30]. Spallation of the coatings occurs by the sequential steps of crack initiation, propagation, and coalescence leaving hot-section components unprotected against the high-temperature environment $[1,31]$. TC is a high-temperature resistant oxide layer and $\mathrm{BC}$ is a connecting layer between TC and the substrate. The TGO layer formed by the diffusion of $\mathrm{O}_{2}$ through TC and the BC layer oxidation has considerably different TEC with the top coat. Due to the thermal expansion coefficient mismatch, thermal cycling may cause stress in the coating resulting in the crack formation and the coating peeling leaving the substrate unprotected $[32,33]$. Understanding the failure mechanisms in the TBC coatings during operation can help us improve the durability of these coatings. Several failure mechanisms have been reported in the literature [34]. Generally, three main mechanisms contribute to TBC failure:

1) Most TBC coatings fail at or near the BC/TGO interface result- ing from elastic strain energy and stress concentration caused by the thickening of TGO and thermal expansion mismatch [35]. Upon cooling down from service temperature to room temperature, the mismatch of TEC between the substrate, BC, and TGO causes high compressive stresses in the ceramic layer [36]. Because of growth strain, high compressive stresses are applied to the TGO. Consequently, the strain energy is released by TGO distortion in the system, which leads to the creation of the tensile and compressive stress gradient. The key reason for nucleation and propagation of cracks in TGO and thereby, the ultimate spallation of the coating is tensile stress [34, 35, 37].

2) In air plasma-sprayed TBCs, spallation also occurs at the splat boundaries of the ceramic top coat. The spallation resistance of the coatings can be increased by altering the coatings architecture, sintering suppression within the top-coat, and using an innovative plasma-spray process [34, 38].

3) Besides thermal-driven damages, TBC damages might be due to mechanical causes such as mechanical fatigue caused by vibration and FOD [34, 39].

\section{TBC modification}

\subsection{New TBCs}

The refractory materials are preferably considered for developing new TBC materials. In this regard, the properties of four ceramic material groups are believed to be more promising for further investigations. These groups are mainly highly-defected zirconium oxide compounds, rare fluorite, and pyrochlore-type earth zirconates, hexa-aluminates, and perovskites. Fluorite and pyrochlore-type earth zirconates have been considered as the most promising choices for the development of new TBC coatings [26, 40].

Predicting the lifetime of TBCs is essential for the improvement of the safety of TBC components [41]. The turbine inlet temperature can be increased to $2000 \mathrm{~K}$ in the new generation of engines having high thrust ratios [42]. In these cases, YSZ-based traditional TBCs could not satisfy the requirements of thermal barriers [43]. In recent years, new TBC materials have been widely explored in order to build coatings that can bear higher temperatures than the traditional TBCs [25]. Some new TBCs include: 1) Lanthanum cerium oxide $\left(\mathrm{La}_{2} \mathrm{Ce}_{2} \mathrm{O}_{7}\right)$ that possess a lower thermal conductivity and a higher TEC than those of YSZ; Lanthanum cerium oxide $\left(\mathrm{La}_{2} \mathrm{Ce}_{2} \mathrm{O}_{7}\right)$ was proposed as a new material for TBC for its low thermal conductivity and large TEC, which is close to the $\mathrm{BCs}$ thermal expansion coefficient. Thermal cycling studies using a $\mathrm{La}_{2} \mathrm{Ce}_{2} \mathrm{O}_{7}$ coating showed that the thermal stability of the $\mathrm{La}_{2} \mathrm{Ce}_{2} \mathrm{O}_{7}$ coating is comparable to the stability of the more traditional YSZ coating. Thus, the lifetime of a single layer of $\mathrm{La}_{2} \mathrm{Ce}_{2} \mathrm{O}_{7}$ is similar to the lifetime of a single layer of YSZ. However, for multi-layer coatings, the $\mathrm{La}_{2} \mathrm{Ce}_{2} \mathrm{O}_{7}$ coatings showed a longer lifetime than the YSZ coatings [44-46].

2) Pyrochlore oxides $\left(\mathrm{A}_{2} \mathrm{~B}_{2} \mathrm{O}_{7}\right)$ are structures comprised of 2 cations with a +3 oxidation state, such as $\mathrm{La}^{3+}$, or $\mathrm{Lu}^{3+}$ (indicated by A), 2 cations with a +4 oxidation state, such as $\mathrm{Zr}^{4+}, \mathrm{Hf}^{4+}$ or $\mathrm{Ti}^{4+}$ (indicated by B), and 7 oxygen anions. $\mathrm{Gd}_{2} \mathrm{Zr}_{2} \mathrm{O}_{7}$ and $\mathrm{La}_{2} \mathrm{Zr}_{2} \mathrm{O}_{7}$ are common examples of these pyrochlore oxides. These materials typically have a lower thermal conductivity, a higher melting point, and a relatively higher TEC compared to YSZ, which makes them suitable for TBC [24, 47-49].

3) Neodymium cerate $\left(\mathrm{Nd}_{2} \mathrm{Ce}_{2} \mathrm{O}_{7}\right)$ has a fluorite type crystal structure, which is stable at high temperatures up to $1600{ }^{\circ} \mathrm{C}$ and has a lower thermal conductivity than YSZ [29]. These thermal properties make this material very promising to be used in advanced TBCs [50-53], such as those used in turbine engines [54, 55].

4) Another material proposed as a new TBC is NiCoCrAlY, which is thermally stable at temperatures ranging from 1200 to $1400{ }^{\circ} \mathrm{C}$ [56]. 


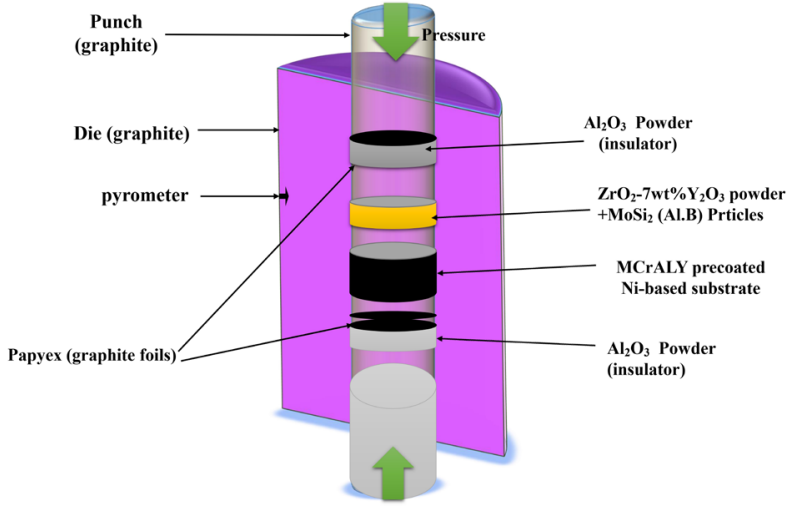

Fig. 1. Self-healing mechanism in TBCs with $\mathrm{MoSi}_{2}$ particles.

This material is used on Ni-based superalloys to improve its resistance to oxidation. At high temperatures, NiCoCrAlY forms an oxide layer between the $\mathrm{BC}$ and the ceramic top coat. The underlying metal is protected from further oxidation by this oxide layer. This oxide layer is also the first place where this TBC fails and thereby, the spallation of TC is promoted [57-59].

\subsection{Changing structure}

Along with the new gas turbine development, there have been many investigations focusing on the introduction of advanced TBC coatings with higher temperature stability and lower thermal conductivity [60]. As mentioned above, the most popular material for TC in TBCs is 7-8 wt. \% YSZ. It shows many advantages; however, it suffers from a few drawbacks and limitations. It is possible for the YSZ coating to undergo an adverse phase transformation upon thermal cycling; also, it may be sintered at elevated temperatures during the service period [34].

The coatings deposited by electron-beam physical vapor deposition (EB-PVD) exhibit improved erosion, strain, and thermal shock resistance due to their columnar microstructure [61]. Three types of EBPVD thermal barrier coatings exist; two-layered, multilayered, and graded TBCs. TBCs with the two-layered structure is the conventional coatings involving the MCrAlY bond coat and YSZ top coat [56]. It has been recently proposed that graded composites of lanthanum hexa-aluminate and alumina present elevated fracture toughness and ductility $[47,62]$. The feasibility of functionally graded thermal barrier coatings by spark plasma sintering was also reported $[63,64]$. The stress between $\mathrm{TC}$ and $\mathrm{BC}$ that is the result of different TEC can be relaxed by graded TBCs. A transition layer with alumina between $\mathrm{TC}$ and $\mathrm{BC}$ is present in these coatings. It has been indicated that the oxidation and thermal shock resistance of graded TBCs are much higher than those of two-layered TBCs [61]. Multi-layered TBCs are commonly utilized for particular applications [56].

\subsection{Nano Structure}

New proposed structural, chemical, and technological approaches for developing new TBCs are not able to deal with all failure factors. Indeed, enhancements of some properties cause a reduction in other characteristics of the materials [65]. To obtain a combination of desired properties, the TBC architecture can be changed and multilayer coatings with engineered layers can be applied, according to their requirements [66]. Compared to conventional TBCs, nanostructure thermal barrier coatings have shown enhanced thermal insulation property and thermal cycling lifetime. Nanozones that consist of unmelted particles shows an utterly porous morphology. These nanopores are homogeneously dis- tributed and besides microcracks, existing voids, and fine grain structure act as phonon scattering centers. Therefore, the thermal conductivity of the coatings is significantly reduced [34]. It has been reported that nanostructured ceramic coatings have excellent mechanical properties, and high TEC [67-74].

Despite the aformentioned properties, the applicability of nanostructured TBCs is skeptical. It is proposed that when nanostructured YSZ coatings are exposed to high-temperature environments, their densification or sintering rates are higher than that of conventional TBCs [73]. As a result of the high sintering rate, coating stiffening (elastic modulus values) and thermal conductivity/ diffusivity increase beyond critical levels; therefore, it might cause premature failure and limit the application of nanostructured TBCs [73].

\section{Self-healing composite TBCs}

In the 1970s, self-healing ceramic materials were first introduced. Self-healing materials are able to repair cracks in ceramics upon heat treatment. Many polymeric, metallic, and concrete-based materials have been reported as self-healing materials over the past few years [75]. Majority of studies in the field of self-healing ceramics are allocated to the use of $\mathrm{SiC}$ for healing, which occurs through the oxidation of $\mathrm{SiC}$ particles and the resulting volume expansion into the cracks [75].

Sloof et al. [76] took the first step to fabricate thermal barrier coatings with self-healing capability. They incorporated boron alloyed $\mathrm{MoSi}_{2}\left(\mathrm{~B}-\mathrm{MoSi}_{2}\right)$ into the $\mathrm{YSZ}$ coating and indicated that the addition of these particles did not create extra stresses during thermal cycles [77]. In the absence of oxidative atmospheres, $\mathrm{B}-\mathrm{MoSi}_{2}$ particles remain solid at $1100{ }^{\circ} \mathrm{C}$, and their TEC is close to that of the YSZ matrix. Additionally, the fluidity of $\mathrm{SiO}_{2}$ at the service temperature increases by alloying the $\mathrm{MoSi}_{2}$ with B, which facilitates the filling of cracks [78]. When cracks are formed, $\mathrm{B}-\mathrm{MoSi}_{2}$ particles embedded into the thermal barrier coating are exposed to a high oxygen potential atmosphere followed by the formation of amorphous $\mathrm{SiO}_{2}$ by the oxidation reaction Amorphous silica flows into generated cracks and comes into direct contact with their walls. This amorphous oxide then reacts with zirconia and form solid reaction products, mainly $\mathrm{ZrSiO}_{4}$, that adhere to the walls [79]. The mechanism of self-healing in TBCs with $\mathrm{MoSi}_{2}$ particles is shown in Fig. 1.

\section{Coating methods}

As mentioned earlier, in an oxygen-containing atmosphere, the material is oxidized rapidly at $1000-1200{ }^{\circ} \mathrm{C}$ [80]. Besides, due to the very porous structure of YSZ, oxygen easily penetrates YSZ, and the ceramic layer is not able to accommodate the compressive stresses to a specific extent $[76,81]$. The thickness of the protective $\mathrm{SiO}_{2}$ coating on the bulk $\mathrm{MoSi}_{2}$ formed above $800{ }^{\circ} \mathrm{C}$ reaches usually several $\mu \mathrm{m}$; therefore, a significant amount of the material in particles is consumed. Moreover, formed $\mathrm{SiO}_{2}$ would react with $\mathrm{ZrO}_{2}$ to form zircon. To prevent these reactions, applying a coating is necessary. Various materials have been studied, such as $\mathrm{ZrSiO}_{4}, \mathrm{Al}_{6} \mathrm{Si}_{2} \mathrm{O}_{13}$, and $\mathrm{Al}_{2} \mathrm{O}_{3}$. However, $\mathrm{Al}_{2} \mathrm{O}_{3}$ is commonly used for coating the self-healing ceramics in TBCs [82]. To enhance their corrosion and oxidation resistance, silicon-containing particles such as $\mathrm{MoSi}_{2}$ and $\mathrm{SiC}$ have been coated by $\mathrm{Al}_{2} \mathrm{O}_{3}$ [83-85].

Atomic layer deposition (ALD) and sol-gel are the two common methods for alumina coating deposition. The sol-gel method is very versatile; however, the system should be in the form of a sol or at least not fully gelated [86]. Although $\mathrm{Al}_{2} \mathrm{O}_{3}$ is the most studied material prepared by sol-gel, the majority of investigations are associated with bulk $\mathrm{Al}_{2} \mathrm{O}_{3}$, particularly for catalytic applications. For the production of particles from the environment, several studies have been carried out on particle 


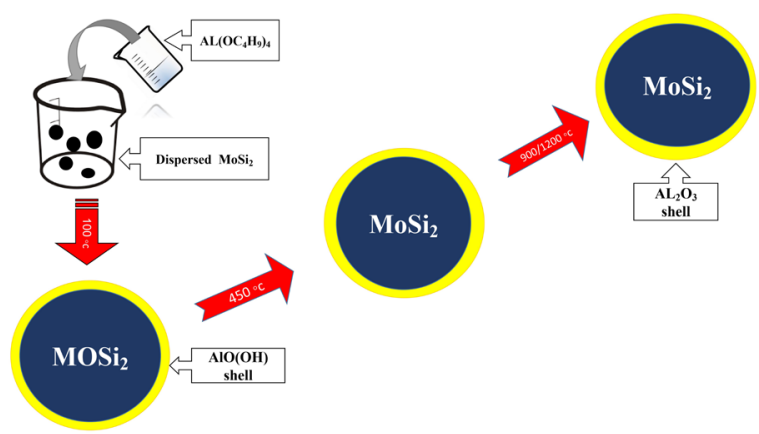

Fig. 2. Coating of $\mathrm{MoSi}_{2}$ particles by the sol-gel method.

coating by sol-gel, for instance, on $\mathrm{SiC}$ [87, 88], magnetic particles [89], and phosphors [90]. As a result of very similar surfaces (a native $\mathrm{SiO}_{2}$ layer), there have been several useful investigations of alumina coating on $\mathrm{SiC}$ by the sol-gel method; however, studies on $\mathrm{MoSi}_{2}$ sol-gel coating with $\mathrm{Al}_{2} \mathrm{O}_{3}$ are rare [91]. The sol-gel production of the $\mathrm{Al}_{2} \mathrm{O}_{3}$ coating on $\mathrm{MoSi}_{2}$ particles is shown schematically in Fig. 2.

ALD is a technique based on chemical vapor deposition, which is an important method to deposit thin films from gas-phase reactants. In this technique, two self-limiting half-reactions occur for the deposition of solid films on the surface. Controlling the thickness of the film is possible due to these self-limiting reactions [92]. ALD is mainly used for the deposition of thin coatings on relatively flat substrates and wafers. Although there are some challenges regarding deposition on particles, it is possible to use this technique for particles. Particles possess a significantly larger surface area compared to wafers requiring the supply of more reactants. The slow mass transfer occurring in a bed of particles is another problem associated with the particle coating, even in the case of high porosity. This leads to the formation of non-homogeneous coatings $[93,94]$.

Using a fluidized bed is a solution to these problems. In this process, the particles are suspended in a gas flow by blowing the gas with sufficient velocity through the bed of particles. As a result, both the gas and particles act as fluids enhancing contact and mixing gas and solid enormously [95].

\section{Self-healing mechanism in thermal barrier coatings}

The addition of $\mathrm{SiC}$ particles to brittle materials such as mullite $\left(3 \mathrm{Al}_{2} \mathrm{O}_{3} \cdot 2 \mathrm{SiO}_{2}\right), \mathrm{Al}_{2} \mathrm{O}_{3}$, and $\mathrm{Si}_{3} \mathrm{~N}_{4}$ could increase the toughness of these materials and it also could give self-healing capability to these materials [96-98]. When $\mathrm{SiC}$ particles interact with cracks at high temperatures, $\mathrm{SiC}$ reacts with $\mathrm{O}_{2}$ resulting in the formation of a silica-based reaction product with volume expansion, which flows into the crack [64]. It is desirable to use self-repair mechanisms at high temperatures to enhance the lifetime of TBC coatings. Using $\mathrm{MoSi}_{2}$ particles in the YSZ matrix for high-temperature crack-healing has been reported [79, 99]. The healing ability of $\mathrm{MoSi}_{2}$ particles is due to the release of viscous $\mathrm{SiO}_{2}$ into the cracks and a subsequent reaction of the formed $\mathrm{SiO}_{2}$ with the matrix through a solid-state reaction. As a result of the reaction, load-bearing crystalline $\mathrm{ZrSiO}_{4}$ is formed, providing enhanced adhesion between the fractured surface and the healing agent [100].

The porous structure of YSZ facilitates the diffusion of oxygen, which might lead to the premature oxidation of the particles, even in the absence of cracks interfering in the healing process in TBCs [101]. Therefore, to prohibit the premature initiation of the healing mechanism in TBCs and maintain the particles in a dormant state, it is required to apply an inert shell that is impenetrable against oxygen on the surface of the actual intermetallic particles [102]. The ideal material for the protection of the particles is $\alpha$-alumina, due to a low permeability for oxygen $[103,104]$ and good thermal stability [105]. When a crack penetrates the $\mathrm{Al}_{2} \mathrm{O}_{3}$ shell surrounding active $\mathrm{MoSi}_{2}$, the healing mechanism is activated [17].

The healing agent incorporated in thermal barrier coatings should have some properties [106] including:1) it should be in the solid phase at the operating temperature because liquids have a large thermal conductivity and large TEC; 2 ) it should be turned into a liquid to wet the crack surfaces and fill the crack; 3) the liquid medium should turn into a solid phase by the reaction between the TBC material and the liquid phase through a solid-state chemical reaction. As a result of this process, the crack is healed by a well-bonded crystalline material having low thermal conductivity [107].

The high-temperature oxidation of $\mathrm{MoSi}_{2}$ has been studied extensively, due to its use as heating elements in many high-temperature furnaces. There are two oxidizable components in the system: molybdenum and silicon, which make the behavior of the system rather complex [108]. The oxidation temperature of $\mathrm{MoSi}_{2}$ ranges between 400 and 500 ${ }^{\circ} \mathrm{C}$, and at temperatures lower than $800{ }^{\circ} \mathrm{C}$, reaction starts as follow:

$2 \mathrm{MoSi}_{2}(\mathrm{~s})+7 \mathrm{O}_{2}(\mathrm{~g}) \rightarrow 2 \mathrm{MoO}_{3}(\mathrm{~s})+4 \mathrm{SiO}_{2}(\mathrm{~s})\left(<800^{\circ} \mathrm{C}\right)$

$\mathrm{Zhu}$ et al. [76] found that above the melting point of $\mathrm{MoO}_{3}$ (approximately $800{ }^{\circ} \mathrm{C}$ ), the formation of $\mathrm{Mo}_{5} \mathrm{Si}_{3}$ and $\mathrm{SiO}_{2}$ is more thermodynamically favored than that of $\mathrm{MoO}_{3}$, according to reaction 3.2. $\mathrm{Mo}_{5} \mathrm{Si}_{3}$ can be further oxidized in the presence of adequate oxygen (according to reaction 3.3). At this temperature, however, the vapor pressure of $\mathrm{MoO}_{3}$ becomes significant, causing most of $\mathrm{MoO}_{3}$ to be removed. Therefore, the formation of the $\mathrm{SiO}_{2}$ scale starts at $800{ }^{\circ} \mathrm{C}$, protecting the $\mathrm{MoSi}_{2}$ and $\mathrm{Mo}_{5} \mathrm{Si}_{3}$ phases.

$5 \mathrm{MoSi}_{2}(\mathrm{~s})+7 \mathrm{O}_{2}(\mathrm{~g}) \rightarrow \mathrm{Mo5Si}_{3}(\mathrm{~s})+7 \mathrm{SiO}_{2}(\mathrm{~s})\left(>800^{\circ} \mathrm{C}\right)$

$\mathrm{Mo}_{5} \mathrm{Si}_{3}(\mathrm{~s})+10.5 \mathrm{O}_{2}(\mathrm{~g}) \rightarrow 5 \mathrm{MoO}_{3}(\mathrm{~g})+3 \mathrm{SiO}_{2}(\mathrm{~s})\left(>800^{\circ} \mathrm{C}\right)$

Porosity in the formed scale due to the significant formation of $\mathrm{MoO}_{3}$ below $800{ }^{\circ} \mathrm{C}$ occurs as a phenomenon referred to the oxidation of $\mathrm{MoSi}_{2}$, which prevents a protective coating formation. If no initial protective coating is formed, oxidation of $\mathrm{MoSi}_{2}$ continues at high rates, which is a challenge in bulk $\mathrm{MoSi}_{2}$ applications. However, a protective coating is needed for particles due to the required thickness of the $\mathrm{SiO}_{2}$ coatings in several $\mu \mathrm{m}$, which is already mentioned in the theory section [109]. Therefore, the consumption of a significant part of the healing particle to form this coating is necessary.

Attempts have been made to alloy $\mathrm{MoSi}_{2}$ with boron and aluminum, due to its interesting high-temperature properties and intermetallic nature [110]. Mao found that boron stabilizes the amorphous phase of $\mathrm{SiO}_{2}$. On the contrary, $\mathrm{MoSi}_{2}$ tends to form separate phases with molybdenum. However, in the presence of molybdenum, no borides are formed from the reaction of boron and silicon [111].

The results indicate that only boron may form a separate phase with molybdenum, which mainly depends on the applied processing conditions for the production of $\mathrm{MoSi}_{2}$. As most of the molybdenum borides have a significant high hardness, boron may increase $\mathrm{MoSi}_{2}$ hardness [112]. In the structure of $\mathrm{MoSi}_{2}, \mathrm{Al}$ can easily substitute $\mathrm{B}$, although it stabilizes the metastable $\mathrm{MoSi}_{2}$ hexagonal phase [113]. As a result, a single phase of $\mathrm{MoSi}_{x} \mathrm{Al}_{\mathrm{y}}$ or a two-phase system with both the hexagonal and tetragonal phase of $\mathrm{MoSi}_{\mathrm{x}} \mathrm{Al}_{\mathrm{y}}$ coexists, depending on the molar ratios of the present elements.

However, the main effect of the presence of aluminum is on its oxidation behavior. In fact, aluminum is preferentially oxidized and reduces $\mathrm{SiO}_{2}$, according to reaction 3.4. This is due to lower $\Delta \mathrm{G}$ of $\mathrm{Al}_{2} \mathrm{O}_{3}$ per mole of oxygen than that of either Mo or $\mathrm{Si}$ [114]. As a result, pest oxidation is limited and the $\mathrm{Al}_{2} \mathrm{O}_{3}$ scale is formed instead of the $\mathrm{SiO}_{2}$ scale [115], depending on the local $\mathrm{Si}, \mathrm{Al}$ and, $\mathrm{O}$ activities.

$4 \mathrm{Al}(\mathrm{s})+3 \mathrm{SiO}_{2}(\mathrm{~s}) \rightarrow 2 \mathrm{Al}_{2} \mathrm{O}_{3}(\mathrm{~s})+3 \mathrm{Si}(\mathrm{s})$

The oxidation of components in $\mathrm{MoSi}_{2}$ and subsequent formation of 


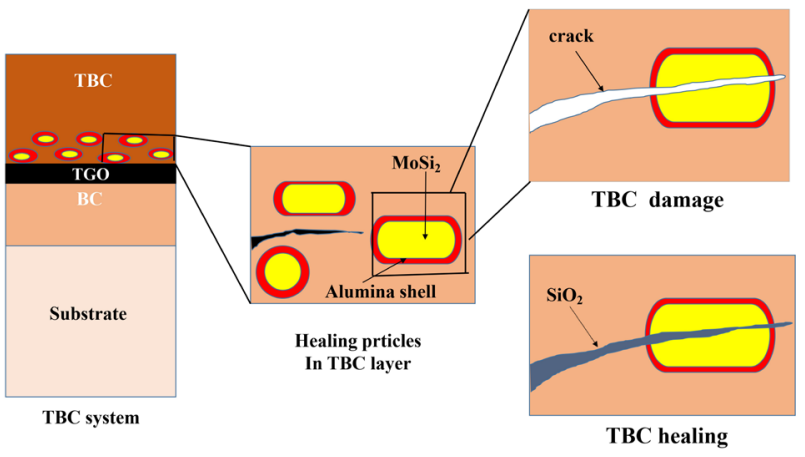

Fig. 3. Preparation of self-healing TBCs using SPS.

ternary oxides lead to significant changes in molar volume and help to fill and close cracks that are desired for the self-healing process. Premature oxidation also results in the accumulation of stress and subsequently coating fracture, as mentioned in the theory section [116].

\section{Application of self-healing composites in TBCs}

The material chosen as a healing agent for an autonomous self-healing TBC must fulfill criteria as follows: (i) the healing material should have a melting temperature higher than $1000{ }^{\circ} \mathrm{C}$ (maximum TBC operating temperature), and its TEC should match the TBC materials, (ii) it should be oxidized and transformed into a liquid to fill cracks and provide direct contact with the surfaces of cracks, (iii) it should be able to wet the crack faces and form a load-bearing material through a solid-state chemical reaction between the TBC material and the liquid [79].

Nozahic et al. [64] embedded encapsulated $\mathrm{MoSi}_{2}$ (B) particles in the YSZ coating to prepare a self-healing TBC. The composite coating deposition on a Ni-based superalloy was carried out using spark plasma sintering (SPS). The coating process is shown in Fig. 3. According to the results, no cracks resulting from thermally induced stresses appeared in the SPS-sintered TBC. This is the result of the CTE difference of the YSZ matrix and $\mathrm{MoSi}_{2}$-based particles.

Ouyang et al. [75] showed that the self-healing agent TiC in YSZ/ $\mathrm{Al}_{2} \mathrm{O}_{3} / \mathrm{TiC}$ composite coatings was able to release $\mathrm{TiO}_{2}$ to heal the pores and cracks in the coatings. Pre-oxidation treatment of the self-healing coating based on $\mathrm{TiC}$ in the furnace at $600^{\circ} \mathrm{C}$ may form a self-healing layer with low-porosity at the interface between $\mathrm{TC}$ and $\mathrm{BC}$, and as a result, it could prevent the formation and growth of the detrimental oxide materials. Hence, the oxidation resistance of the coating was improved by the self-healing process. Nevertheless, according to the thermal cycle test, a thick layer of the TiC-self-healing coating induced the stress above the stress limit in ceramic coatings.

Ouyang et al. [117] used APS to fabricate self-healing TBCs based on YSZ/SiC-self-healing (SAZ) structure. They demonstrated that the self-healing occurred during SAZ coating after oxidation at the temperature of $720^{\circ} \mathrm{C}$, which resulted in filling the remaining cracks/pores in the $\mathrm{SAZ}$ coating. Moreover, due to the comprised oxidation resisting materials, $\mathrm{Al}_{2} \mathrm{O}_{3}$ in the $\mathrm{SAZ}$ coating and its dense structure, the oxidation resistance of TBCs was improved after coating with SAZ. Consequently, the resistance against spallation in the YSZ/SAZ also increased, which was verified using an ideal mode assessing the TBC stress intensity. They also applied a cyclic high-temperature oxidation test on YSZ and YSZ/ $\mathrm{SAZ}$ coatings. The results showed that the spallation resistance was increased in the YSZ/SAZ coatings by a thoughening effect occurred after high-temperature oxidation.

Nguyen et al. [118] developed a self-healing material based on a composite of $\mathrm{Ni}$ and $\mathrm{Y}_{2} \mathrm{Ti}_{2} \mathrm{O}_{7}$. In order to study the crack-healing behavior, Vickers indenter was employed to intentinally generate the cracks on the surface of the composite, followed by an annealing process in an oxidizing atmosphere. They suggest that the depositing of $\mathrm{NiO}$ into the cracks is the main crack-healing mechanism. In fact, the oxidation of the Ni fillers led to the formation of $\mathrm{NiO}$ during annealing. According to XRD and SEM results, the complete healing of the cracks was obtained using $10 \mathrm{vol} \%$ Ni filler.

Kulczyk-Malecka et al. [119] established Yttria-partially stabilized zirconia (YPSZ) $/ \mathrm{MoSi}_{2}$ composites to render self-healing ability and enhance the thermal stability of the matrix. In this method, decomposition of $\mathrm{MoSi}_{2}$ at the elevated temperatures results in the volumetrically expanding product which heals the cracks. Furthermore, they focused on the comparison between the conventional YPSZ and the composites containing $\mathrm{MoSi}_{2}$ particles in terms of the TEC and the fracture toughness. It was found that the produced $\mathrm{MoSi}_{2}$ composites have a similar TEC and fracture toughness to the conventional YPSZ, indicating small mismatch stresses induced by elevated temperature. The cracks introduced by indentation have shown such a composite system is able to independently perform the self-healing reaction.

Kurniadi et al. [120] encapsulate $\mathrm{MoSi}_{2} \mathrm{~B}$ particles in YSZ coatings using a novel approach for in situ shell formation. The healing particles were alloyed with $\mathrm{Al}$. The results showed that the addition of $12 \mathrm{wt} \%$ of $\mathrm{Al}$ resulted in a homogeneous distribution of $\mathrm{Mo}\left(\mathrm{Si}_{1-x}, \mathrm{Al}_{\mathrm{x}}\right)_{2}$ and the formation of exclusive alumina through selective oxidation of aluminum at $1100^{\circ} \mathrm{C}$. In comparison with pure Argon, oxidation in lower $\mathrm{O}_{2}$ pressure using $\mathrm{CO} / \mathrm{CO}_{2}$ led to a more exclusive alumina formation. But, composite oxidation in the $\mathrm{CO} / \mathrm{CO}_{2}$ exhibited the simultaneous formation of $\mathrm{Al}$ oxide, Si oxide, and mixed alumina-silica. This shows that partial reduction of YSZ plays a role in particle oxidizing. However, the shell provided protection for particles was observed in microcapsule stability test in laboratory air and at $1100^{\circ} \mathrm{C}$ for $100 \mathrm{~h}$. The crack-gap filling experiment demonstrated no significant difference in the healing behavior of in situ encapsulated $\mathrm{MoSi}_{2} \mathrm{~B}$ and pre-encapsulated when the composites were exposed to the temperature of $1100{ }^{\circ} \mathrm{C}$ for $16 \mathrm{~h}$.

Wang et al. [77] developed YSZ-La-Mo-Si coatings (YSZ-LMS) using the plasma spraying method for protecting carbon/carbon $(\mathrm{C} / \mathrm{C})$ composites. Raw materials for the production of the coating were YSZ, $\mathrm{MoSi}_{2}$, and $\mathrm{LaB}_{6}$. The results showed that the YSZ-LMS coating protected the composites at $1500{ }^{\circ} \mathrm{C}$ for $50 \mathrm{~h}$. A denser oxide glass layer of $\mathrm{Zr}-\mathrm{Y}$-La-Si-O was formed due to the formation of $\mathrm{La}_{2} \mathrm{O}_{3}, \mathrm{Y}_{2} \mathrm{SiO}_{5}, \mathrm{Zr}-$ $\mathrm{SiO}_{4}$, and $\mathrm{SiO}_{2}$, which leads to the solid phase volume expansion and a decrease in the $\mathrm{SiO}_{2}$ volatilization. As a result of the volume expansion at high temperatures, compressive stress is generated within the coating restraining the crack initiation and propagation, leading to the improvement of the oxidation resistance of the coatings. The activation energy of high-temperature oxidation for the coated $\mathrm{C} / \mathrm{C}$ composites was obtained to be $74.466 \mathrm{~kJ} \mathrm{~mol}^{-1}$ at $1300-1500{ }^{\circ} \mathrm{C}$.

To prepare TBCs with the self-healing ability, Carnicer et al. [121] used an aqueous suspension of $\mathrm{Al}_{2} \mathrm{O}_{3}$ and $\mathrm{SiCY}$-TZP. To prevent the $\mathrm{SiC}$ oxidation as a self-healing agent, suspension plasma spraying was utilized for the deposition of the coating. The results demonstrated that the $\mathrm{SiC}$ particles were oxidized during the PS process and the dispersion of the unmelted particles was observed in a partially melted $\mathrm{Al}_{2} \mathrm{O}_{3} / \mathrm{Y}$-TZP matrix. This reveals the potential self-healing ability of the prepared coating.

Using embedded $\mathrm{MoSi}_{2}(\mathrm{~B})$ healing particle oxidation, Derelioglu et al. [79] developed a new method for the fabrication of self-healing TBCs. The oxidative decomposition of the healing agents resulted in the amorphous $\mathrm{SiO}_{2}$ formation which flowed into created cracks and wetted the crack faces. Thereafter, solid $\mathrm{ZrSiO}_{4}$ was formed due to the reaction between $\mathrm{SiO}_{2}$ and $\mathrm{ZrO}_{2}$ based TBC coating establishing a strong bond between the matrix material and the healing agent causing a complete filling of cracks. Even when cracks are not present in the coating, the decomposition reaction can occur resulting from the oxygen transparen- 
cy of the $\mathrm{ZrO}_{2}$-based matrix. This led to premature decomposition and undesirable pore filling of the coatings.

In general, the self-healing TBC samples made by SPS indicate an enhanced resistance against thermal cycling in the air at the temperature of $1100{ }^{\circ} \mathrm{C}$. The results show that the borosilicate or silicate phase partially fills some cracks and there is a zircon phase that connects both surfaces of the crack. The intended self-healing effect of partially yttria-stabilized zirconia-based TBCs reinforced with $\mathrm{MoSi}_{2}(\mathrm{~B})$-based particles was confirmed by the observations $[64,122,123]$.

\section{Conclusions and future insights}

Thermal barrier coatings have been offered for several applications in the industry to improve the efficiency of advanced gas-turbine engines. $\mathrm{SiC}, \mathrm{MoSi}_{2}, \mathrm{TiC}$, etc. have been shown to act as a self-healing agent and are able to heal the cracks/pores in the coatings. The good resistance of self-healing TBC samples against thermal cycling at high temperatures in the air indicates the feasibility and the good performance of these coatings in-service conditions. It has been deduced that the borosilicate or silicate phase partially fills some cracks and there is a zircon phase that connects the surfaces of cracks. In the near future, hopefully, other composite materials will be tested for self-healing applications in TBCs and a further improvement in the physical and thermal properties of the barrier coatings will be investigated.

\section{Acknowledgments}

The authors received no financial support for the research, authorship and/or publication of this article.

\section{Conflict of Interest}

All authors declare no conflicts of interest in this paper.

\section{REFERENCES}

[1] B. Zhou, S. Yang, C. Wang, X. Hu, W. Song, J. Cai, Q. Xu, N. Sang, The characterization of free radical reaction in coal low-temperature oxidation with different oxygen concentration, Fuel 262 (2020) 116524

[2] I. Tajzad, E. Ghasali, Production methods of CNT-reinforced Al matrix composites: a review, Journal of Composites and Compounds 2(1) (2020) 1-9.

[3] J. Daraei, Production and characterization of PCL (Polycaprolactone) coated TCP/nanoBG composite scaffolds by sponge foam method for orthopedic applications, Journal of Composites and Compounds 2(1) (2020) 45-50.

[4] Z. Goudarzi, A. Ijadi, A. Bakhtiari, S. Eskandarinezhad, N. Azizabadi, M.A Jazi, Sr-doped bioactive glasses for biological applications, Journal of Composites and Compounds 2(3) (2020) 105-109.

[5] H. Ullah, K.A. M Azizli, Z.B. Man, M.B.C. Ismail, M.I. Khan, The Potential of Microencapsulated Self-healing Materials for Microcracks Recovery in Self-healing Composite Systems: A Review, Polymer Reviews 56(3) (2016) 429-485.

[6] S.O. Omid, Z. Goudarzi, L.M. Kangarshahi, A. Mokhtarzade, F. Bahrami, Self-expanding stents based on shape memory alloys and shape memory polymers, Journal of Composites and Compounds 2(3) (2020) 92-98

[7] M. Arefian, M. Hojjati, I. Tajzad, A. Mokhtarzade, M. Mazhar, A. Jamavari, A review of Polyvinyl alcohol/Carboxiy methyl cellulose (PVA/CMC) composites for various applications, Journal of Composites and Compounds 2(3) (2020) 6976.

[8] F. Nozahic, D. Monceau, C. Estournès, Thermal cycling and reactivity of a $\mathrm{MoSi}_{2} / \mathrm{ZrO}_{2}$ composite designed for self-healing thermal barrier coatings, Materials \& Design 94 (2016) 444-448.

[9] Z. Derelioglu, S. Ponnusami, S. Turteltaub, S. Van der Zwaag, W. Sloof, Healing particles in self-healing thermal barrier coatings, (2013).

[10] S. Nasibi, K. Alimohammadi, L. Bazli, S. Eskandarinezhad, A. Mohammadi, N. Sheysi, TZNT alloy for surgical implant applications: A systematic review, Journal of Composites and Compounds 2(3) (2020) 62-68.

[11] M.D. Hager, Self-healing materials, Handbook of Solid State Chemistry (2017) 201-225

[12] K. Zhang, H.W. Jang, Q. Van Le, Production methods of ceramic-reinforced
Al-Li matrix composites: A review, Journal of Composites and Compounds 2(3) (2020) 77-84.

[13] L.-Y. Yu, R.-L. Li, H.-L. Wu, S.-F. Zhang, M.-W. Chai, X.-X. Shen, M. Hong, H. Lin, Selective Removal of $\mathrm{Cu}^{2+}$ Ion in Aqueous Solution by Poly (Acrylic Acid/ Acrylamide) Hydrogel, Chinese Journal of Analytical Chemistry 48(8) (2020) e20098-e20106.

[14] C. Chen, S. Chen, Z. Guo, W. Hu, Z. Chen, J. Wang, J. Hu, J. Guo, L. Yang, Highly efficient self-healing materials with excellent shape memory and unprecedented mechanical properties, Journal of Materials Chemistry A (2020).

[15] Z.-Y. Wei, B. Cheng, J. Wang, M.-J. Liu, H.-N. Cai, Extend the thermal cyclic lifetime of $\mathrm{La}_{2} \mathrm{Zr}_{2} \mathrm{O}_{7} /$ YSZ DCL TBCs by reducing modulus design on a toughening ceramic surface, Surface and Coatings Technology 374 (2019) 134-143

[16] H. Xia, C. Li, H. Chen, Green preparation of CuI particles in dielectric barrier discharge for colorimetric determination of trace mercury in comparison with atomic fluorescence spectrometric determination, Microchemical Journal 146 (2019) 1169-1172.

[17] A.L. Carabat, M.J. Meijerink, J.C. Brouwer, E.M. Kelder, J.R. van Ommen, S. van der Zwaag, W.G. Sloof, Protecting the $\mathrm{MoSi}_{2}$ healing particles for thermal barrier coatings using a sol-gel produced $\mathrm{Al}_{2} \mathrm{O}_{3}$ coating, Journal of the European Ceramic Society 38(7) (2018) 2728-2734.

[18] M. Belmonte, Advanced Ceramic Materials for High Temperature Applications, Advanced Engineering Materials 8(8) (2006) 693-703.

[19] F. Cernuschi, P. Bison, A. Moscatelli, Microstructural characterization of porous thermal barrier coatings by laser flash technique, Acta Materialia 57(12) (2009) 3460-3471.

[20] M. Dietrich, V. Verlotski, R. Vassen, D. Stöver, Metal-Glass Based Composites for Novel TBC-Systems, Materialwissenschaft und Werkstofftechnik: Materials Science and Engineering Technology 32(8) (2001) 669-672.

[21] T. Ouyang, X. Fang, Y. Zhang, D. Liu, Y. Wang, S. Feng, T. Zhou, S. Cai, J. Suo, Enhancement of high temperature oxidation resistance and spallation resistance of SiC-self-healing thermal barrier coatings, Surface and Coatings Technology 286 (2016) 365-375.

[22] C. Yu, H. Liu, C. Jiang, Z. Bao, S. Zhu, F. Wang, Modification of NiCoCrAlY with Pt: Part II. Application in TBC with pure metastable tetragonal $\left(\mathrm{t}^{\prime}\right)$ phase YSZ and thermal cycling behavior, Journal of materials science \& technology 35(3) (2019) 350-359.

[23] G. Pulci, J. Tirillò, F. Marra, F. Sarasini, A. Bellucci, T. Valente, C. Bartuli, High temperature oxidation of MCrAlY coatings modified by $\mathrm{Al}_{2} \mathrm{O}_{3}$ PVD overlay, Surface and Coatings Technology 268 (2015) 198-204.

[24] K.M. Doleker, Y. Ozgurluk, A.C. Karaoglanli, Isothermal oxidation and thermal cyclic behaviors of YSZ and double-layered $\mathrm{YSZ} / \mathrm{La}_{2} \mathrm{Zr}_{2} \mathrm{O}_{7}$ thermal barrier coatings (TBCs), Surface and Coatings Technology 351 (2018) 78-88.

[25] M. Mohammadi, A. Kobayashi, S. Javadpour, S. Jahromi, Evaluation of hot corrosion behaviors of $\mathrm{Al}_{2} \mathrm{O}_{3}-\mathrm{YSZ}$ composite $\mathrm{TBC}$ on gradient MCrAlY coatings in the presence of $\mathrm{Na}_{2} \mathrm{SO}_{4}-\mathrm{NaVO}_{3}$ salt, Vacuum 167 (2019) 547-553.

[26] S. Mahade, D. Zhou, N. Curry, N. Markocsan, P. Nylén, R. Vaßen, Tailored microstructures of gadolinium zirconate/YSZ multi-layered thermal barrier coatings produced by suspension plasma spray: Durability and erosion testing, Journal of Materials Processing Technology 264 (2019) 283-294.

[27] M. Bahamirian, S. Hadavi, M. Farvizi, A. Keyvani, M. Rahimipour, Thermal Durability of YSZ/Nanostructured $\mathrm{Gd}_{2} \mathrm{Zr}_{2} \mathrm{O}_{7}$ TBC Undergoing Thermal Cycling, Oxidation of Metals 92(5-6) (2019) 401-421.

[28] J. Wang, J. Sun, Q. Jing, B. Liu, H. Zhang, Y. Yongsheng, J. Yuan, S. Dong, X. Zhou, X. Cao, Phase stability and thermo-physical properties of $\mathrm{ZrO}_{2}-\mathrm{CeO}_{2}-\mathrm{TiO}_{2}$ ceramics for thermal barrier coatings, Journal of the European Ceramic Society 38(7) (2018) 2841-2850

[29] N. Ejaz, L. Ali, A. Ahmad, M. Mansoor, M.M. Asim, A. Rauf, K. Mehmood, Thermo-Physical Properties Measurement of Advanced TBC Materials with Pyrochlore and Perovskite Structures, Key Engineering Materials, Trans Tech Publ, 2018, pp. 236-244.

[30] A.A. Abubakar, A.F.M. Arif, S.S. Akhtar, Evolution of internal cracks and residual stress during deposition of TBC, Ceramics International (2020).

[31] A. Ghoshal, M. Murugan, M.J. Walock, A. Nieto, L. Bravo, B. Barnett, M. Pepi, C. Hoffmeister Mock, J. Swab, S. Hirsch, Sandphobic coatings and surface modification of hot section components of next generation VTOL engines: current and future research efforts, 2018 Joint Propulsion Conference, 2018, p. 4831.

[32] O.P. Golim, N. Prastomo, H. Izzudin, S. Hastuty, R. Sundawa, E. Sugiarti, K.A.Z. Thosin, Synthesis of alumina ceramic encapsulation for self-healing materials on thermal barrier coating, Journal of Physics: Conference Series 985 (2018) 012036.

[33] L. Lim, S. Meguid, Modeling and characterisation of depletion of aluminium in bond coat and growth of mixed oxides in thermal barrier coatings, International 
Journal of Mechanics and Materials in Design (2019) 1-17.

[34] A.H. Pakseresht, Production, Properties, and Applications of High Temperature Coatings, IGI Global2018.

[35] J. Jiang, L. Jiang, Z. Cai, W. Wang, X. Zhao, Y. Liu, Z. Cao, Numerical stress analysis of the TBC-film cooling system under operating conditions considering the effects of thermal gradient and TGO growth, Surface and Coatings Technology 357 (2019) 433-444.

[36] R. Takahashi, J. Assis, F.P. Neto, D. Reis, Heat treatment for TGO growth on NiCrAlY for TBC application, Materials Research Express 6(12) (2020) 126442. [37] X. Zhang, K. Zhou, M. Liu, C. Deng, C. Deng, J. Mao, Z. Deng, Mechanisms governing the thermal shock and tensile fracture of PS-PVD 7YSZ TBC, Ceramics International 44(4) (2018) 3973-3980.

[38] J. Kulczyk-Malecka, X. Zhang, J. Carr, F. Nozahic, C. Estournès, D. Monceau, A.L. Carabat, W.G. Sloof, S. van der Zwaag, P.J. Withers, P. Xiao, Thermo mechanical properties of SPS produced self-healing thermal barrier coatings containing pure and alloyed $\mathrm{MoSi}_{2}$ particles, Journal of the European Ceramic Society 38(12) (2018) 4268-4275.

[39] J. Mitrić, J. Križan, J. Trajić, G. Križan, M. Romčević, N. Paunović, B. Vasić, N. Romčević, Structural properties of $\mathrm{Eu}^{3+}$ doped $\mathrm{Gd}_{2} \mathrm{Zr}_{2} \mathrm{O}_{7}$ nanopowders: Far-infrared spectroscopy, Optical Materials 75 (2018) 662-665.

[40] G. Moskal, A. Jasik, M. Mikuśkiewicz, S. Jucha, Thermal resistance determination of $\mathrm{Sm}_{2} \mathrm{Zr}_{2} \mathrm{O}_{7}+8 \mathrm{YSZ}$ composite type of TBC, Applied Surface Science 515 (2020) 145998

[41] M. Gupta, N. Markocsan, X.-H. Li, R.L. Peng, Improving the lifetime of suspension plasma sprayed thermal barrier coatings, Surface and Coatings Technology 332 (2017) 550-559.

[42] Y. Fukushima, M. Arai, K. Ito, T. Suidzu, Fusion and TBC Penetration Characteristics of Volcanic Ash Collected from Active Volcano, Journal of Thermal Spray Technology (2020) 1-15.

[43] S. Budinovskii, D. Chubarov, P. Matveev, A. Smirnov, Deposition and Properties of the Ceramic TBC Layer Prepared by Magnetron Sputtering, Russian Metallurgy (Metally) 2019(12) (2019) 1280-1284.

[44] X. Cao, R. Vassen, W. Fischer, F. Tietz, W. Jungen, D. Stöver, Lanthanum-Cerium Oxide as a Thermal Barrier-Coating Material for High-Temperature Applications, Advanced Materials 15(17) (2003) 1438-1442.

[45] H. Zhang, J. Zeng, J. Yuan, P. Liang, X. Zhou, S. Chen, S. Duo, S. Dong, J. Jiang, L. Deng, Spray power-governed microstructure and composition, and their effects on properties of lanthanum-cerium-tantalum-oxide thermal barrier coating, Ceramics International (2020).

[46] Y. Bai, W. Fan, K. Liu, Y. Kang, Y. Gao, F. Ma, Gradient $\mathrm{La}_{2} \mathrm{Ce}_{2} \mathrm{O}_{7} / \mathrm{YSZ}$ thermal barrier coatings tailored by synchronous dual powder feeding system, Materials Letters 219 (2018) 55-58.

[47] R. Vaßen, M.O. Jarligo, T. Steinke, D.E. Mack, D. Stöver, Overview on advanced thermal barrier coatings, Surface and Coatings Technology 205(4) (2010) 938-942.

[48] G. Moskal, Microstructure and thermal properties of Sm.

[49] K.M. Doleker, Y. Ozgurluk, H. Ahlatci, A.C. Karaoglanli, Evaluation of oxidation and thermal cyclic behavior of $\mathrm{YSZ}, \mathrm{Gd}_{2} \mathrm{Zr}_{2} \mathrm{O}_{7}$ and $\mathrm{YSZ} / \mathrm{Gd}_{2} \mathrm{Zr}_{2} \mathrm{O}_{7} \mathrm{TBCs}$, Surface and Coatings Technology 371 (2019) 262-275.

[50] R. Ianoş, P. Barvinschi, Solution combustion synthesis of calcium zirconate, $\mathrm{CaZrO}_{3}$, powders, Journal of solid state chemistry 183(3) (2010) 491-496.

[51] K. Neufuss, J. Dubsky, P. Rohan, B. Kolman, P. Chraska, L.-M. Berger, R. Zieris, S. Thiele, M. Nebelung, Structure and properties of $\mathrm{CaZrO}_{3}$ coatings prepared by WSP and APS spraying, ITSC 2003: International Thermal Spray Conference 2003: Advancing the Science and Applying the Technology, 2003, pp. 1541-1546.

[52] M. Pollet, S. Marinel, G. Desgardin, $\mathrm{CaZrO}_{3}$, a Ni-co-sinterable dielectric material for base metal-multilayer ceramic capacitor applications, Journal of the European Ceramic Society 24(1) (2004) 119-127.

[53] G. Di Girolamo, F. Marra, M. Schioppa, C. Blasi, G. Pulci, T. Valente, Evolution of microstructural and mechanical properties of lanthanum zirconate thermal barrier coatings at high temperature, Surface and Coatings Technology 268 (2015) 298-302.

[54] L.A. Noveed Ejaz*, Akhlaq Ahmad, Muhammad Mansoor, Muhammad Muneeb Asim, Abdul Rauf, Khalid Mehmood, Thermo-Physical Properties Measurement of Advanced TBC Materials with Pyrochlore and Perovskite Structures, 778 (2018).

[55] Z. Yang, P. Zhang, W. Pan, Y. Han, M. Huang, H. Chen, Q. Gong, C. Wan, Thermal and oxygen transport properties of complex pyrochlore $\mathrm{RE}_{2} \mathrm{InTaO}_{7}$ for thermal barrier coating applications, Journal of the European Ceramic Society (2020).

[56] H. Xu, H. Guo, Thermal barrier coatings, Elsevier2011.
[57] H. Lau, Influence of yttria on the cyclic lifetime of YSZ TBC deposited on EB-PVD NiCoCrAlY bondcoats and its contribution to a modified TBC adhesion mechanism, Surface and Coatings Technology 235 (2013) 121-126.

[58] S. Nouri, S. Sahmani, M. Asayesh, M. Aghdam, Improvement of high-temperature oxidation resistance of $\gamma$-TiAl intermetallic alloy by YSZ-NiCoCrAlY coating using APS process, Materials Research Express 6(12) (2019) 126541

[59] J. Shi, T. Zhang, B. Sun, B. Wang, X. Zhang, L. Song, Isothermal oxidation and TGO growth behavior of NiCoCrAlY-YSZ thermal barrier coatings on a Nibased superalloy, Journal of Alloys and Compounds 844 (2020) 156093.

[60] M. Peters, C. Leyens, U. Schulz, W.A. Kaysser, EB-PVD thermal barrier coatings for aeroengines and gas turbines, Advanced engineering materials 3(4) (2001) 193-204

[61] L.B. Chen, Yttria-stabilized zirconia thermal barrier coatings-a review, Surface Review and Letters 13(05) (2006) 535-544.

[62] B.R. Lawn, N.P. Padture, H. Cait, F. Guiberteau, Making ceramics" ductile", Science 263(5150) (1994) 1114-1116.

[63] A.H. Pakseresht, A.H. Javadi, M. Bahrami, F. Khodabakhshi, A. Simchi, Spark plasma sintering of a multilayer thermal barrier coating on Inconel $738 \mathrm{su}-$ peralloy: Microstructural development and hot corrosion behavior, Ceramics International 42(2, Part A) (2016) 2770-2779.

[64] F. Nozahic, C. Estournès, A.L. Carabat, W.G. Sloof, S. van der Zwaag, D. Monceau, Self-healing thermal barrier coating systems fabricated by spark plasma sintering, Materials \& Design 143 (2018) 204-213.

[65] S.-J. Park, M.-K. Seo, T.-J. Ma, D.-R. Lee, Effect of chemical treatment of Kevlar fibers on mechanical interfacial properties of composites, Journal of colloid and interface science 252(1) (2002) 249-255.

[66] A.H. Pakseresht, A.H. Javadi, E. Ghasali, A. Shahbazkhan, S. Shakhesi, Evaluation of hot corrosion behavior of plasma sprayed thermal barrier coatings with graded intermediate layer and double ceramic top layer, Surface and Coatings Technology 288 (2016) 36-45.

[67] N.P. Padture, M. Gell, E.H. Jordan, Thermal barrier coatings for gas-turbine engine applications, Science 296(5566) (2002) 280-284

[68] A. Aygun, A.L. Vasiliev, N.P. Padture, X. Ma, Novel thermal barrier coatings that are resistant to high-temperature attack by glassy deposits, Acta Materialia 55(20) (2007) 6734-6745.

[69] B. Ercan, K.J. Bowman, R.W. Trice, H. Wang, W. Porter, Effect of initial powder morphology on thermal and mechanical properties of stand-alone plasma-sprayed 7 wt.\% $\mathrm{Y}_{2} \mathrm{O}_{3}-\mathrm{ZrO}_{2}$ coatings, Materials Science and Engineering: A 435 (2006) 212-220

[70] L. Xie, D. Chen, E.H. Jordan, A. Ozturk, F. Wu, X. Ma, B.M. Cetegen, M. Gell, Formation of vertical cracks in solution-precursor plasma-sprayed thermal barrier coatings, Surface and Coatings Technology 201(3-4) (2006) 1058-1064.

[71] G. Shanmugavelayutham, A. Kobayashi, Mechanical properties and oxidation behaviour of plasma sprayed functionally graded zirconia-alumina thermal barrier coatings, Materials chemistry and physics 103(2-3) (2007) 283-289.

[72] B.-K. Jang, H. Matsubara, Influence of porosity on thermophysical properties of nano-porous zirconia coatings grown by electron beam-physical vapor deposition, Scripta materialia 54(9) (2006) 1655-1659.

[73] R. Lima, B. Marple, Nanostructured YSZ thermal barrier coatings engineered to counteract sintering effects, Materials Science and Engineering: A 485(1-2) (2008) 182-193.

[74] H. Chen, X. Zhou, C. Ding, Investigation of the thermomechanical properties of a plasma-sprayed nanostructured zirconia coating, Journal of the European Ceramic Society 23(9) (2003) 1449-1455.

[75] T. Ouyang, J. Wu, M. Yasir, T. Zhou, X. Fang, Y. Wang, D. Liu, J. Suo, Effect of TiC self-healing coatings on the cyclic oxidation resistance and lifetime of thermal barrier coatings, Journal of Alloys and Compounds 656 (2016) 992-1003. [76] W.G. Sloof, Self healing in coatings at high temperatures, Self healing materials, Springer2007, pp. 309-321.

[77] C. Wang, K. Li, X. Shi, J. Sun, Q. He, C. Huo, Self-healing YSZ-La-MoSi heterogeneous coating fabricated by plasma spraying to protect carbon/carbon composites from oxidation, Composites Part B: Engineering 125 (2017) 181-194. [78] S.T. Nguyen, T. Nakayama, M. Takeda, N.N. Hieu, T. Takahashi, Development of Yttrium Titanate/Nickel Nanocomposites with Self Crack-Healing Ability and Potential Application as Thermal Barrier Coating Material, MATERIALS TRANSACTIONS (2020) MT-MN2019006

[79] Z. Derelioglu, A.L. Carabat, G.M. Song, S.v.d. Zwaag, W.G. Sloof, On the use of B-alloyed $\mathrm{MoSi}_{2}$ particles as crack healing agents in yttria stabilized zirconia thermal barrier coatings, Journal of the European Ceramic Society 35(16) (2015) 4507-4511

[80] H.E. Eaton, G.D. Linsey, E.Y. Sun, K.L. More, J.B. Kimmel, J.R. Price, N. Miriyala, $\mathrm{EBC}$ protection of $\mathrm{SiC} / \mathrm{SiC}$ composites in the gas turbine combustion en- 
vironment: continuing evaluation and refurbishment considerations, Turbo Expo: Power for Land, Sea, and Air, American Society of Mechanical Engineers, 2001, p. V004T02A010.

[81] S.C. Singhal, Advances in solid oxide fuel cell technology, Solid state ionics 135(1-4) (2000) 305-313

[82] M.J. Meijerink, Coating of $\mathrm{MoSi}_{2}$ healing particles for self-healing thermal barrier coatings, Chemical Engineering Materials Science and Engineering (2015). [83] R. Dutton, R. Wheeler, K. Ravichandran, K. An, Effect of heat treatment on the thermal conductivity of plasma-sprayed thermal barrier coatings, Journal of Thermal Spray Technology 9(2) (2000) 204-209.

[84] S. Maria Jose, C.T. Mathew, J. K.Thomas, Fabrication of Dysprosium doped $\mathrm{Y}_{2} \mathrm{O}_{3}$ infrared transparent ceramic materials by a microwave sintering technique, Materials Today: Proceedings 24 (2020) 2383-2393.

[85] M. Pavić-Čolić, Multi-velocity and multi-temperature model of the mixture of polyatomic gases issuing from kinetic theory, Physics Letters A 383(24) (2019) 2829-2835.

[86] N. Avci, I. Cimieri, P.F. Smet, D. Poelman, Stability improvement of moisture sensitive $\mathrm{CaS}$ : $\mathrm{Eu}^{2+}$ micro-particles by coating with sol-gel alumina, Optical Materials 33(7) (2011) 1032-1035.

[87] J.J. Gibson, Y. Yi, S.J. Birks, Watershed, climate, and stable isotope data (oxygen-18 and deuterium) for 50 boreal lakes in the oil sands region, northeastern Alberta, Canada, 2002-2017, Data in Brief 29 (2020) 105308.

[88] P. Benda, A. Kalendová, Anticorrosion Properties of Pigments based on Ferrite Coated Zinc Particles, Physics Procedia 44 (2013) 185-194

[89] S. Rabadzhiyska, L. Kolaklieva, V. Chitanov, T. Cholakova, R. Kakanakov, N. Dimcheva, K. Balashev, Mechanical, wear and corrosion behavior of CrN/TiN multilayer coatings deposited by low temperature unbalanced magnetron sputtering for biomedical applications, Materials Today: Proceedings 5(8, Part 2) (2018) 16012-16021.

[90] L.W. Martin, Y.H. Chu, R. Ramesh, Advances in the growth and characterization of magnetic, ferroelectric, and multiferroic oxide thin films, Materials Science and Engineering: R: Reports 68(4) (2010) 89-133.

[91] R. Mateos, G. Baeza, B. Sarriá, L. Bravo, Improved LC-MSn characterization of hydroxycinnamic acid derivatives and flavonols in different commercial mate (Ilex paraguariensis) brands. Quantification of polyphenols, methylxanthines, and antioxidant activity, Food Chemistry 241 (2018) 232-241.

[92] M. Tomczyk, A. Mahajan, A. Tkach, P.M. Vilarinho, Interface-based reduced coercivity and leakage currents of $\mathrm{BiFeO}_{3}$ thin films: A comparative study, Materials \& Design 160 (2018) 1322-1334.

[93] S. Bhattacharya, K. Mo, Z. Mei, D. Seidman, B. Stepnik, M.J. Pellin, A.M. Yacout, Improving stability of ALD ZrN thin film coatings over U-Mo dispersion fuel, Applied Surface Science (2020) 147378.

[94] L. Chen, Yttria-stabilized zirconia thermal barrier coatings - a review, Surface Review and Letters 13(05) (2006) 535-544.

[95] F. Yao, K. Ando, M.C. Chu, S. Sato, Static and cyclic fatigue behaviour of crack-healed $\mathrm{Si}_{3} \mathrm{~N}_{4} / \mathrm{SiC}$ composite ceramics, Journal of the European Ceramic Society 21(7) (2001) 991-997.

[96] K. Takahashi, M. Yokouchi, S.-K. Lee, K. Ando, Crack-Healing Behavior of $\mathrm{Al}_{2} \mathrm{O}_{3}$ Toughened by $\mathrm{SiC}$ Whiskers, Journal of the American Ceramic Society 86(12) (2003) 2143-2147

[97] M. Chu, S. Sato, Y. Kobayashi, K. Ando, Damage healing and strengthening behaviour in intelligent mullite/SiC ceramics, Fatigue \& Fracture of Engineering Materials \& Structures 18(9) (1995) 1019-1029.

[98] W. Sloof, S. Turteltaub, A. Carabat, Z. Derelioglu, S. Ponnusami, G. Song, 219 Crack healing in yttria stabilized zirconia thermal barrier coatings, Self Healing Materials: Pioneering Research in the Netherlands (2015) 219.

[99] M.E. Smith, Recent progress in solid-state NMR of low- $\gamma$ nuclei, Annual Reports on NMR Spectroscopy, Academic Press2001, pp. 121-175.

[100] S.C. Singhal, Advances in solid oxide fuel cell technology, Solid State Ionics 135(1) (2000) 305-313

[101] X. Fan, W. Huang, X. Zhou, B. Zou, Preparation and characterization of $\mathrm{NiAl}-\mathrm{TiC}-\mathrm{TiB}_{2}$ intermetallic matrix composite coatings by atmospheric plasma spraying of SHS powders, Ceramics International (2020).

[102] A.H. Heuer, Oxygen and aluminum diffusion in $\alpha-\mathrm{Al}_{2} \mathrm{O}_{3}$ : How much do we really understand?, Journal of the European Ceramic Society 28(7) (2008) 14951507.

[103] Y. Oishi, W.D. Kingery, Self-Diffusion of Oxygen in Single Crystal and Polycrystalline Aluminum Oxide, The Journal of Chemical Physics 33(2) (1960) 480-486.

[104] M. MUNRO, Evaluated material properties for a sintered alpha-alumina, Journal of the American Ceramic Society 80(8) (1997) 1919-1928.

[105] S. Xie, C. Song, Z. Yu, S. Liu, F. Lapostolle, D. Klein, C. Deng, M. Liu, H. Liao, Effect of environmental pressure on the microstructure of YSZ thermal barrier coating via suspension plasma spraying, Journal of the European Ceramic Society (2020).

[106] Y. Heng, N. Feng, Y. Liang, D. Hu, Lignin-retaining porous bamboo-based reversible thermochromic phase change energy storage composite material, International Journal of Energy Research 44(7) (2020) 5441-5454.

[107] B. Mazères, C. Desgranges, C. Toffolon-Masclet, D. Monceau, Experimental study and numerical simulation of high temperature $\left(1100-1250^{\circ} \mathrm{C}\right)$ oxidation of prior-oxidized zirconium alloy, Corrosion Science 103 (2016) 10-19.

[108] D. Seo, M. Sayar, K. Ogawa, $\mathrm{SiO}_{2}$ and $\mathrm{MoSi}_{2}$ formation on Inconel 625 surface via SiC coating deposited by cold spray, Surface and Coatings Technology 206(11-12) (2012) 2851-2858.

[109] Y. Xu, X. Liu, L. Gu, J. Wang, P. Schützendübe, Y. Huang, Y. Liu, Z. Wang, Natural oxidation of amorphous $\mathrm{Cu}_{\mathrm{x}} \mathrm{Zr}_{1-\mathrm{x}}$ alloys, Applied Surface Science 457 (2018) 396-402.

[110] K.R. Lim, W.T. Kim, E.-S. Lee, S.S. Jee, S.Y. Kim, D.H. Kim, A. Gebert, J. Eckert, Oxidation resistance of the supercooled liquid in $\mathrm{Cu}_{50} \mathrm{Zr}_{50}$ and $\mathrm{Cu}_{46} \mathrm{Zr}_{46} \mathrm{Al}_{8}$ metallic glasses, Journal of Materials Research 27(8) (2012) 1178.

[111] B. Wang, D. Huang, N. Prud'Homme, Z. Chen, F. Jomard, T. Zhang, V. Ji, Diffusion mechanism of $\mathrm{Zr}$-based metallic glass during oxidation under dry air, Intermetallics 28 (2012) 102-107.

[112] H. Over, A. Seitsonen, Oxidation of metal surfaces, Science 297(5589) (2002) 2003-2005.

[113] S. Aygün, S. Klinge, Continuum mechanical modeling of strain-induced crystallization in polymers, International Journal of Solids and Structures 196-197 (2020) 129-139.

[114] Y. Wang, D. Su, H. Ji, X. Li, Z. Zhao, H. Tang, Gradient structure high emissivity $\mathrm{MoSi}_{2}-\mathrm{SiO}_{2}-\mathrm{SiOC}$ coating for thermal protective application, Journal of Alloys and Compounds 703 (2017) 437-447.

[115] X. Jing, H.-Y. Mi, X.-F. Peng, L.-S. Turng, Biocompatible, self-healing, highly stretchable polyacrylic acid/reduced graphene oxide nanocomposite hydrogel sensors via mussel-inspired chemistry, Carbon 136 (2018) 63-72.

[116] T. Ouyang, S. Xiong, Y. Zhang, D. Liu, X. Fang, Y. Wang, S. Feng, T. Zhou, J. Suo, Cyclic oxidation behavior of SiC-containing self-healing TBC systems fabricated by APS, Journal of Alloys and Compounds 691 (2017) 811-821.

[117] T.N. Son Thanh Nguyen, Masatoshi Takeda, Nguyen Ngoc Hieu, Tsuyoshi Takahashi, Development of Yttrium Titanate/Nickel Nanocomposites with Self Crack-Healing Ability and Potential Application as Thermal Barrier Coating Material, (2020).

[118] I.I. Kurniadi Isnu, On the in situ encapsulation of MoSi2B healing particles in YSZ TBCs: Self-healing of thermal barrier coatings (TBCs), (2016).

[119] V. Carnicer Cervera, E. Cañas-Recacha, M.J. Orts Tarí, R. Moreno, M.D. Salvador Moya, P. Carpio Cobo, L. Navarro, E. Sánchez-Vilches, Characterization of thermal barriers coatings of $\mathrm{Y}-\mathrm{TZP} / \mathrm{Al}_{2} \mathrm{O}_{3} / \mathrm{SiC}$ composite obtained by suspension plasma spraying, (2017).

[120] B. Xiao, X. Huang, T. Robertson, Z. Tang, R. Kearsey, Sintering resistance of suspension plasma sprayed 7YSZ TBC under isothermal and cyclic oxidation, Journal of the European Ceramic Society 40(5) (2020) 2030-2041.

[121] F. Nozahic, A.L. Carabat, W. Mao, D. Monceau, C. Estournès, C. Kwakernaak, S. Van Der Zwaag, W.G. Sloof, Kinetics of zircon formation in yttria partially stabilized zirconia as a result of oxidation of embedded molybdenum disilicide, Acta Materialia 174 (2019) 206-216. 